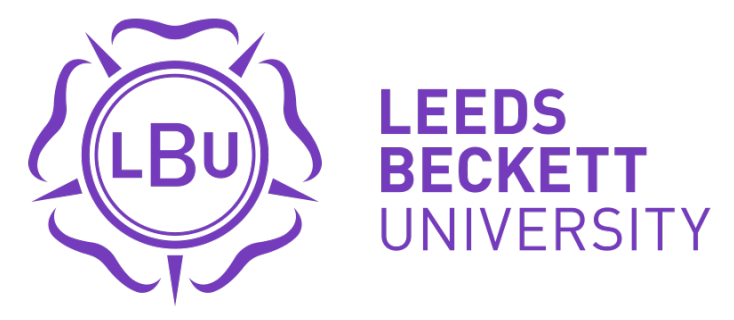

Citation:

Oriade, A and Robinson, P (2019) Prosuming Tourist Information: Asking Questions on TripAdvisor. International Journal of Tourism Research, 21 (1). pp. 134-143. ISSN 1099-2340 DOI: https://doi.org/10.1002/jtr.2247

Link to Leeds Beckett Repository record:

https://eprints.leedsbeckett.ac.uk/id/eprint/5444/

Document Version:

Article (Accepted Version)

This is the peer reviewed version of the following article: Oriade, A, Robinson, P. Prosuming tourist information: Asking questions on TripAdvisor. Int J Tourism Res. 2019; 21: 134- 143, which has been published in final form at https://doi.org/10.1002/jtr.2247. This article may be used for non-commercial purposes in accordance with Wiley Terms and Conditions for Use of Self-Archived Versions.

The aim of the Leeds Beckett Repository is to provide open access to our research, as required by funder policies and permitted by publishers and copyright law.

The Leeds Beckett repository holds a wide range of publications, each of which has been checked for copyright and the relevant embargo period has been applied by the Research Services team.

We operate on a standard take-down policy. If you are the author or publisher of an output and you would like it removed from the repository, please contact us and we will investigate on a case-by-case basis.

Each thesis in the repository has been cleared where necessary by the author for third party copyright. If you would like a thesis to be removed from the repository or believe there is an issue with copyright, please contact us on openaccess@leedsbeckett.ac.uk and we will investigate on a case-by-case basis. 
International Journal of Tourism Research

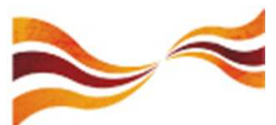

\section{Prosuming Tourist Information: Asking Questions on TripAdvisor}

\begin{tabular}{|r|l|}
\hline Journal: & International Journal of Tourism Research \\
\hline Manuscript ID & Draft \\
\hline Wiley - Manuscript type: & Research Article \\
\hline Keywords: & prosumption, TripAdvisor, destination, information \\
\hline \multicolumn{3}{c}{} \\
\\
\multicolumn{3}{c}{ SCHOLARONE } \\
\\
\end{tabular}

Oriade, A.; Robinson, P. 


\section{Prosuming Tourist Information: Asking Questions on TripAdvisor}

\section{Introduction}

As tourism has evolved, post-Fordist structures of consumption have been used to exemplify the shifting nature of tourist consumption from package holidays to more independent, niche market, tailored experiences (Munt, 1994; Urry, 2002; Shaw \& Williams, 2004). Yet increasingly tourism relies not upon the traditional idea of consumption, but on the notion of co-creation (Pappalepore, Maitland \& Smith, 2014) and presumption (Ritzer, Dean \& Jurgenson, 2012). The shift in consumption pattern and increased reliance on co-creation warrant visitors' adoption of strategies for coping with the trend. The transformational power of technology, particularly information and communication technology (ICT) makes the adoption feasible. Likewise, destinations in turn have to keep up with this pace recognising the contributing role of the internet in production and consumption of tourism, and the growing importance of user generated content (UGC) as one of the primary sources of information (Inversini, Cantoni, \& Buhalis, 2009).

The internet provides a great deal of information quickly, but in potentially large qualities which require careful navigation to find accurate information (Béliveau \& Garwood 2001). A considerable range of online resources exist including official destination websites, alternative destination websites, advertising driven sites, attraction website, review websites and general information websites, as well as online communities which serve as information centres (Stepchenkova, Mills \& Jiang 2007). 
Pabel and Prideaux (2016) pointed out the dearth of studies in small regional leisure destination travels and identify a need for further research which assesses the different pretrip planning needs of both first-time visitors and repeat visitors. They suggest that such a study could elucidate specific strategies for engaging different market segments through social media. Whilst there has been considerable research around tourist review sites such as Trip Advisor, and its role in destination experience (Miguéns, Baggio \& Costa, 2008; O’Connor, 2008; Kladou \& Mavragani, 2015) the studies have been based upon the content and format of reviews posted on the site. Others have focussed on e-word of mouth (e-WoM) (Davis \& Khazanchi, 2008; Jalilvand \& Samiei, 2012; Tham, Croy \& Mair, 2013). Whilst a number of studies have addressed the role of eWOM in tourism destination choice (Litvin, Goldsmith, \& Pan, 2008; Park \& Gretzel, 2007; Tham, Croy \& Mair, 2013) little attention has been paid to the role of review site fora as a source of tourist information.

In this paper, attention is given to the role of the Trip Advisor Forum, which, as illustrated here, increasingly provides answers to rather perfunctory, but very important questions about access, opening arrangements and suitability. This is a role traditionally performed by Tourist Information Centres (TICs) and Destination Marketing Organisations (DMOs), (together with private sector businesses), yet in an environment, such as UK, where public sector funding and support has been reduced for these services, there is an increased engagement with digital platforms such as Trip Advisor, where consumers are playing the role of customer service staff on behalf of DMOs, providing key information about the attractions and destinations people are interested in visiting. This paper therefore aims to improve our theoretical 
knowledge regarding the type of queries raised by potential travellers on digital platforms by developing a model which helps in identifying and classifying such queries. It also seeks to delineate the manner in which these queries are answered.

\section{Literature Review}

Ritzer et al. (2012) observed that interest in co-creation and prosumption has gained considerable traction in the $21^{\text {st }}$ Century. Despite only becoming prevalent in the last two decades, prosumption was first explained by Toffler (1980) as bringing together the processes of production and consumption, an idea first explored by Karl Marx and later by McLuhan and Nevitt (1972). Prosumption was subsequently discussed by Kotler (1986) as "The Prosumer Movement" and Dabholkar (1990), whilst the related concept of 'value co-creation' (Humphreys \& Grayson, 2008) has been of interest within tourism literature. Ritzer et al. (2012) argues that prosumption has always existed, but has been understood as the separate processes of production and consumption. (Ritzer, 2009; Ritzer et al., 2012). Xie, Bagozzi and Troye (2008, p110) define prosumption (within tourism) as "value creation activities undertaken by the consumer that result in the production of products they eventually consume and that become their consumption experiences". This is consistent with the notion of value co-creation, where tourists also contribute to co-creation through their own performances (Lusch \& Vargo, 2006; Haldrup \& Larsen, 2010; Rakic \& Chambers, 2012).

The intangible nature of service experiences, particularly tourism, means that there is a higher perception of risk associated with the purchase. Word of Mouth and eWOM gives some sense that this risk is minimised (risks include functional, 
financial, psychological, and social risks (Fodness \& Murray, 1997) as the reviews and information provided is independent of the service provider. For this reason, information search is a central theme in the travel and tourism literature. Risk perception has been widely discussed in tourism literature, with an increasing body of work focusing on the worry that is associated with these risks. This can be described as "a tendency to view ambiguous or uncertain situations as threatening (Butler \& Matthews, 1987). The process of worrying assist in problem solving strategies to relieve the concerns which are causing the worry in the first place (Miceli \& Castelfanchi, 2005, Freeston, Rhéaume, Letarte, Dugas, \& Ladouceur, 1994).

TripAdvisor offers visitors insights about what they might experience. Online consumer reviews can be considered as a form of electronic word of mouth (eWOM). Word of mouth describes communication about products and services which are independent of the business itself, (Silverman, 2001) and is, as a consequence perceived to be a more trustworthy and honest review of the quality of services and products. Traditionally word of mouth explains communication between two people, but the internet, and Web 2.0 in particular has enabled word of mouth marketing to become global (Chatterjee, 2001), ubiquitous (Jalilvand \& Samiei, 2012) and impactful (Mayzlin, 2006). Referred to as eWOM, (Davis \& Khazanchi, 2008; Godes \& Mayzlin, 2004; Kiecker \& Cowles, 2001; Xia \& Bechwati, 2008) it is defined as "any positive or negative statement made by potential, actual, or former customers about a product or company which is made available to multitude of the people and institutes via the Internet" (Hennig-Thurau, Gwinner, Walsh \& Gremler, 2004). The fact that eWOM can be accessed anywhere at any time and forwarded to other 
consumers leads to information diffusion (Abubakar \& llkan, 2013). The impact of eWOM and online review sites more broadly has created a form of communication which empowers consumers and providers creating two-way communication channels between consumers and businesses (Litvin et al., 2008). This new hypermedia has led to increased engagement with the internet as a source of information about products and services (Litvin et al.,2008; Li, Robinson \& Oriade, 2017).

Review sites play a key role in tourist decision making, providing simultaneous information and recommendations about products and services - where, official DMO websites provide only information, (Bickart \& Schindler, 2001; Park \& Gretzel, 2007). Increasing commercialisation of sites such as TripAdvisor mean that they also now serving multiple functions. Whilst TripAdvisor is not traditionally viewed as a form of social media, there is some element of social media to the interaction which occurs through the online forum space - this is clear when aligned with Kietzmann et al., (2011, p. 241) definition of social media as employing "mobile and web-based technologies to create highly interactive platforms via which individuals and communities share, co-create, discuss and modify user-generated content'. Research by Pabel and Prideaux (2016) suggested that despite its obvious differences with social media platforms such as Facebook and Twitter, it was seen as a Social Media tools by travel decision makers. Their research revealed that $49.1 \%$ of respondents nominated it as their most popular social media platform for general travel information search, consistent with Xiang and Gretzel, (2010). Pabel and Prideaux (2016) suggest that DMOs require strategies to maximize the use of TripAdvisor (and social media more broadly) which may include training for 
managers to help grow positive feedback and to address complaints - yet the very section where tourists are looking for information is dominated by casual users (residents and non-residents of each destination).

White and White, (2007) and Kim, Fesenmaier and Johnson (2013) identify that social media and online travel communities can play a key role in the creation and consumption of the tourist experience through a visit, influencing day to day decisions about where to go, what to do and where to eat. Indeed Tussyadiah and Fesenmaier (2009) argue that social media can provide new experiences after the trip by reinforcing the meaning (or potential reinterpretations) of the trip. Kim et al., (2013) suggest that the best way to understand the impact of social media on the travel experience can be achieved by studying the nature of interactions between social media and individuals. Such social constructivism has origins in psychology, sociology and communication studies where individual experiences contribute to gathered knowledge which is then shared with others, (DiMaggio et al. 2001; Vygotsky 1978). Clearly, social media plays a key role in mediating and co-creating the tourist experience (O’Dell \& Billing 2005).

Online communities are defined as "groups of people with common interests and practices that communicate regularly and for some duration in an organized way over the Internet through a common location or mechanism" (Ridings, Gefen, \& Arinze 2002, p. 273). Furthermore, online communities are considered to be more honest, (Gretzel, Yoo, \& Purifoy, 2007; Tsaur et al., 2014) and the information contained within to be more valuable than information which is formally published (Ridings, Gefen \& Arinze, 2002). 
The host-guest relationship is the established one example of co-creation and prosumption in tourism (Meuter et al, 2000) and enables both parties to contribute to the creation of an experience. By contrast, information available in online communities is also considered first-hand and impartial, (Crotts 1999), provided not only by previous visitors but also by destination residents (Arsal et al, 2010). Arsal et al (2010) noted that previous research has not examined the role of residents in online travel communities, where they may engage in discussions, provide information and provide word of mouth recommendations. This reflects a more active and innovative participation in the process of production (Prebensen \& Foss, 2011).

The internet, and Web 2.0 specifically, has contributed to the emergence of prosumption (Toffler, 1980), effectively employing consumers to work on behalf of businesses (Ritzer, 2012). Consumers help businesses with their marketing activities, make recommendations, post images and, increasingly, answer questions in peer to peer forums all at no cost. The factual, pragmatic detail of actually arranging a visit requires detailed research to establish opening times, accessibility, ease of access, public transport and a host of other personalised information requirements. As a consequence, a number of Forums, including TripAdvisor, increasingly illustrate that consumers are using these discussions areas to find out this information.

Access to such a significant range of data has, therefore, provided an opportunity to explore the role of TripAdvisor as a platform for prosumption, employing previous travellers and destination residents to help potential travellers to find out simple 
information about destination offerings - information which is often available online anyway. This raises a number of important questions about trust, experience, and the creation of a prosumption based visitor economy where DMOs may become increasingly redundant in providing frontline services for consumers.

Fischhoff at al. (2004) explore the potential for worry affecting travel choices and even leading to trip cancellation. In response to this, Larsen Brun \& Ogaard (2009) developed the Tourist Worry Scale (TWS) which comprises eight items assessing the degree to which tourists worry about their trips. Concerns invariably focus on issues such as crime, terrorism, general safety or becoming lost, but also consider a general concern about things going wrong, issues with travel arrangements, tickets and access. Larsen et al., (2009) suggest that there are unresolved issues which connect risk, worry and tourism.

The risk of general disappointment, defined as "a negative emotional state resulting when perceived expectations do not compare to reality (Smith, Fredrickson, Loftus, \& Nolen-Hoeksema, 2003), with the travel experience is a further cause for worrying. Often, such disappointment may be rooted in the failure to realise the anticipated experience which was predicated on advertising promises and media campaigns (Beeton, 2005, 2008; Butler, 2011) and personal illusion, (Bonifield \& Cole, 2007). This feeling derives from both extrinsic factors and intrinsic factors, (Michalko et al., 2015). It may be reasonable to suggest that asking questions on a Forum will generate honest answers which mitigate the risk of disappointment and reduce the level of worry experienced before a visit takes place. 


\section{Methodology}

In order to achieve the objectives of this research qualitative data collection and analysis of questions and answer postings of potential and past visitors on TripAdvisor forum of ten destinations in the UK were used. Although there are several other travel review sites, including Virtual Tourist and IgoUgo. Pabel and Prideaux (2016) identified TripAdvisor as the most popular. Banerjee and Chua (2016) also suggest that collecting data from a popular platform such as TripAdvisor facilitates gleaning findings that would hold practical significance; hence its selection for this research project.

Data were manually extracted, similar to Zhang at al., (2017), from TripAdvisor forum pages of ten small UK destinations. Many studies involving travel review sites (e.g. Banerjee \& Chua 2016; Liu et al., 2017) use web crawlers or scrapers; however, due to the qualitative nature of this study a more practical and purposeful approach had been adopted. The basic unit of analysis in this study is a posting sporting a question by an original poster (OP) who starts a thread discussion. A thread is made up of a lead posting (a question) follow by responses from the online community who consist of experienced travellers/posters (EP), resident (RE), potential travellers (PT), and unknown members (UN). As noted, the labelling is based on Arsal et al (2010) because this facilitate clear identification of the research subjects. A thread may not necessarily have all these members, however, qualification for inclusion was that there is a lead posting followed by responses from member(s) of the community. Postings generated before January 2017 were collected for Ashby De La Zouch (8), Evesham (9), Kidderminster (5), Leek (3), Loughborough (28), Market Bosworth (9), Market Harborough (11), Newark on Trent (5), Stafford (15) and Witney (8). A total of 
101 postings were harvested. Each destination was chosen because it is a historic market town, with at least two visitor attractions, an accommodation offer and part of an attractive destination grouping but without being the central town or main attractor within a Destination Management Organisation which serves the town as art of its destination area.

As the extracted data were generally unstructured, cleaning was undertaken. A research assistant was employed to organise the data in a logical format without distorting the original form. Each thread was treated as a distinct document with all subjects clearly identified and labelled as earlier stated. Also, the research assistant had to double check that individual postings met the selection criteria. After the cleaning process, a total of 97 useable postings were realised. The discarded postings happened to be duplication of entries or random questions not relevant to the study e.g. 'Nice place to live?'. With this process, a more structured and useable format was derived. Table 1 shows a breakdown of postings analysed in this study.

\section{Table 1 About Here}

Utilising NVivo11, extracted data was analysed employing thematic networks. Arsal et al (2010) suggested, as an outcome from their research, that further use of argumentation theory as a tool for analysing online postings which form a conversation could, by using thematic networks, reveal further insight into issues. 


\section{Results and Analysis}

Initial coding of the data relating to questions asked by travellers was based on Arsal et al's (2010) seven theme of accommodation, itinerary, transportation, food \& beverage, money, safety \& health and destination information. Two other main themes: retail and general were later included. Thematic analysis was used in order to identify patterns of meaning across the data that would help address the research objective of classifying queries raised by travellers on TripAdvisor. As the analysis progressed the main organising themes were rationalised to six: transportation, food \& beverage, accommodation, itinerary, retail and destination information. The theme of money was dropped because there were no sub-themes that build up to this organising theme. For example, there were no queries regarding how to carry money or foreign exchange even though some foreign travellers asked questions on the study forums. Discussions relating to money focussed on cost and price. Safety and health was equally excluded because this did not emerge as a distinct theme in this context. General which was initially included as an organising theme was also excluded as some of the sub-themes such as "change of management" and "refurbishment information" can be categorised under destination information. Retail was retained because of its distinct contribution to the categorisation. The shared themes with Arsal's et al (2010) organising themes differ in their make-up in some regards due to the different context. For example, in this study itinerary has two subthemes namely: route planning and activities.

The following section presents an explanation of the general organising themes (see Figure 1) regarding the types of questions asked by travellers and potential travellers on destinations' forum on TripAdvisor in the UK's small destination context. 


\section{General organising themes of travellers' questions}

Transportation: this is one of the most discussed themes, with subthemes of public transport, car hire/rental, driving (private vehicle), transport facilities and cost of transportation. Public transport appeared 62 times (henceforth, collection frequency or $\mathrm{CF}$ ) in 17 threads (henceforth document frequency or DF). Train $(\mathrm{CF}=105$; $\mathrm{DF}=$ 22) which was the most discussed means of transport falls under this sub-theme and parking $(C F=66 ; D F=20)$ falls under the transport facilities sub-theme. Car usage in terms of parking and rental was also extensively discussed (CF = 62; DF $=19)$.

Accommodation: the two key sub-theme in this category are cost and place to stay. Information enquiry on places to stay $(C F=73 ; D F=30)$ at affordable prices constitute the main thrust of this theme. This study, in the context of small UK destinations, found where to stay was discussed in the context of self-catering accommodation, caravan parks and hotels $(C F=94 ; D F=27)$ and bed and breakfast accommodation. Hotel can further be divided into luxury and affordable on one hand and town centre or quiet, countryside location on the other.

Itinerary: the two main sub-themes under this category are route planning and activities. OPs enumerate their planned journeys and solicit for information on how to make the best of their time and money. Also, enquires here relate to what to do and where to go. Often responses point to the town $(C F=99 ; D F=36)$. However, information relating to town centres overlap with queries on accommodation, transportation and food and beverage. 
Food and Beverage: travellers' enquiries regarding food $(\mathrm{CF}=41$; $\mathrm{DF}=17)$ and beverage centred round places to eat $(C F=36 ; D F=23)$, how to find them and value for money. Pub ( $C F=69 ; \mathrm{DF}=24)$ appeared to be one of the frequently mentioned places but the key sub-themes under this category are regular eating and drinking, seasonal and special occasion dining, speciality food and price.

Destination Information: broadly speaking the sub-theme under queries relating to destination information are: things to do, places to visit, facilities at the destination and protocol at events. Information here relate to anything specific to the destination (Arsal et al., 2010). Surprisingly no query relating to weather was spotted given the unpredictability of UK weather; this may be due to the fact that OPs were mainly from within the UK.

Retail: this theme appears quite crucial in the context of this study. it consists of three basic themes namely: antique shopping, local market and supplies for hobbies. Shopping $(C F=73 ; D F=30)$ featured in many queries ranging from specialised antique shopping to general shopping.

\section{Figure 1 About Here}

\section{Level of importance attached to questions by posters}

Another interesting finding in this study relates to importance attached to the questions asked by the original posters. Generally, travel evoke some level of risk perception especially where significant expenditure is involved, such as the annual family holiday. In this study a theme that emerged relates to the importance that 
travellers attached to their trip and/or the seriousness attached to certain types of trip e.g. short breaks for memorable occasions and romance, and attendance of important family events. In one of the postings that show some level of uncertainty, a poster wrote:

"My husband has a business trip to Loughborough in September, and my daughter and I would like to accompany him to do some sightseeing while he is working. My first time to the UK and I'm a little intimidated, as our area here in the US isn't big on public transportation".

Another example of one of such queries that depict a sense of importance and an undertone of not wanting the experience to go wrong is illustrated in this query:

Hi all. My hubby and I are off to Alton towers end of september. We need to stay for a few days somewhere after the hussle and bussle of alton towers. Somewhere Romantic, a touch of luxury either a gorgeous hotel or cottage. Somewhere with a relaxing big bath and gorgeous features. We just dont want to be too far out away that we cant get in the car and go out. I love my hubby alot but I don't want to sit in a room miles from anywhere or anywhere too basic as it is a romantic relaxing break but I don't know the areas at all. Dannah Farm looks lovely. Any ideas anyone?

\section{Nature of response generated}

Coding for the responses generated by travellers' questions produced ten organising themes namely: direct answer, advice and suggestion, directives, recommendation, 
further query, additional information, observation, product description, invitation and regrets. Cluster analysis (see Figure 2) of the types of responses generated by the questions asked by traveller indicated two clusters with advice and suggestion, direct answer, recommendation, additional information, observation and product description in one cluster, and directives, further probing, invitation and regrets in the other. The first category of responses seems to be based on good knowledge of the subject matter. The former is termed knowledge response and the latter as a fallow response.

The findings of the study reveal that the other category of responses (fallow response) denotes the lack of a concrete answer to the question. This category is further divided into two types of response termed guarded response and lax responses. The guarded response shows a level of cautiousness in providing answer either due to lack of knowledge or because of insufficient information. Where there is lack of sufficient information a probing query is thrown back at the OP for clarity and clarification. In a case of lack of knowledge, the OP is referred to an appropriate source such as organisation website, government guideline or industry code of conduct. The lax response seems somewhat detrimental because appropriate answers are not offered neither is the OP pointed to a different source to obtain the right answer. The lax response consists of two categories: invitation and regrets. Invitation responses are not objective. Rather than answering the question they provide alternatives by inviting the OP to consider another option which may not be a direct substitute to their choice. For instance, an OP asked for a nice place for Mother's Day Lunch. The following response was provided by an UN 
Come join us at the diamond studio. We are having a charity day on Thursday the 12th of March. Have some tea, cakes and we are also having make overs done as well with lancome professionals. Come along and share the love.

The 'regret' response is more detrimental. Responses in this category are sarcastic and unhelpful. An example is the following comment volunteered by an EP "Not sure why anyone would want to spend too much time there". Another comment reads "I would be more concerned that it is a (brand) Hotel!"

\section{Figure 2 About Here}

\section{Proposed Model}

At a much deeper level some relationship can be identified in terms of risk potential tourist are able to take e.g. special occasions which travellers do not want to be messed up hence there is perception of risk. The seriousness people attach to their travel even at domestic, regional small destination level is a deciding factor. Also, there is a notion that people want their experience to be protected especially when travelling with loved ones.

In addressing this study objective, the WOLF model (Fig 3) is presented and it postulates that there are two deciding factors that help in classifying online queries raised by potential traveller or user of tourism service. The first is the level of information a query can generate. According to Li et al. (2017) the internet has made it possible for consumers to access a vast array of information online, through formal and informal sources of information. The other factor is the level of precaution taken 
by the traveller or seriousness attached to the future experience. In general tourism literature appears to offer a promise of memorable experiences to consumers. There is, of course, a risk that such experiences may fall short of this expectation. It is always concluded that major travel such as family annual holidays that attract high financial outlay are more involving hence demand more planning to ensure that memorable experiences are achieved. The experiential nature of tourism is such that there is an element of risk, given the fluid nature by which individuals measure their travel experiences (Robinson, Lueck \& Smith, 2013). Risk perception does not preclude travel to and within small, regional destinations or the demand for tourism services in such regions, but requires careful planning. Based on these two premises, queries on TripAdvisor Forums are categorised into W - wonderland query, $\mathrm{O}$ - onboard query, $\mathrm{L}$ - lame duck query and $\mathrm{F}$ - flagship query in order to develop a conceptual model to explain the phenome witnessed in the data analysis.

\section{Figure 3 About Here}

1. Wonderland query: The query in this class does not necessarily need much precaution or risk perception on the part of the traveller but they generate a lot of responses. This may be due to the popularity of the topic or the availability of information regarding the topic. Due to the vast amount of information available EPs and other posters have the tendency to supply unsolicited and sometimes unrelated information. The sheer volume of information supplied can be overwhelming. 
2. Onboard query: Onboard queries are basic questions that have straight answer. It is so named as it is assumed that people can easily take responses generated 'on-board'.

3. Lame duck query: Lame duck query is a query that depict that the OP has a high level of perceived risk but answers generated by the query are straightforward. Information generated in this category may not necessarily provide overwhelming responses. Responses are clear and directly address the question. Such responses may not generate confusion or controversy, and are likely to be simpler than the OP thought they might be.

4. Flagship query: This type of query embodied questions that generate a vast amount of information as a result of the seriousness the traveller attached it. The type of responses generated may refer the OP to additional sources of information and to conduct further searches. The vast amount of information and controversy may render the OP more indecisive and overwhelmed. EPs and other posters tend to be more cautious, their role is more advisory than recommending. This may be attributed to the high level of seriousness of the query.

\section{Discussion and Conclusion}

The study results demonstrate understanding the notion of prosumption among travellers who ask questions and share information online can facilitate the way value co-creation process is managed. The results further emphasize the centrality quality of information and risk perception in the co-creation process. It is fascinating to observe in many ways notable, the internet, through social media and travel review sites, continues to enhance contributions visitors make in creating their 
experiences and that of their fellow tourists. This is particularly true of TripAdvisor which enables traveller to gather information about what they might experience through reviews or get answers to questions about destinations they intend to visit through destination forums. This paper set out to examine the type of queries raised by potential travellers on digital platforms and developed a model which helps in identifying and classifying such queries. It also delineates the way these queries are answered.

This study found somewhat similar themes as Arsal et al. (2010), which include transportation, accommodation, itinerary, retail, food \& beverage and destination information. These themes are generally referred to as the components of tourism, hence it is not surprising that questions asked by travellers on travel sites relate to these elements. However, the study goes further to summarise questions asked as: (1) Direct questions - questions that necessitate specific answers. These questions are simple in nature because there are definite and not far-fetched answer; (2) Casual questions - these are questions with 'no string attached'. The enquirer often specify that they are not particular about brand or form; they only seek functionality; (3) Questions with emotional attachment; (4) Complex questions - this type of questions is a combination of other categories. The complexity will depend on whether the question is a combination of multiple direct questions or direct question mixed with a level of risk perception; and (5) Incomplete (ambiguous) questions questions in this category often require further enquiry due to lack of completeness or clarity. This last category does not necessarily mean the questions asked are invalid, the category further give credence to the fact that online review sites provide 
some form of communication channels which facilitate two-way communication between enquirers and responders (Litvin et al., 2008).

Interesting findings were also revealed in the nature and types of responses generated by the questions. The findings of this study suggest that responses provided may be based on knowledge of the subject matter which will be depicted in advice and suggestion, direct answer, recommendation, additional information, observation and product description. On the other hand, lack of knowledge may be exhibited due to contributors not knowing the answer or because the OP did not ask a clear question which may lead to online community contributor(s) giving directive directives, probing further, sending invitation for alternative and/or registering their regrets. Sending invitation for alternatives that are not relevant to the OP's need and/or passing snide comments are contrary to Gretzel, Yoo, and Purifoy, (2007) and Tsaur et al., (2014) submission that online communities are honest, and Ridings et al. (2002) findings that information on review platforms are valuable than information formally published. This has implications for both the destination and the traveller.

The general terms that can be used in describing the responses in relation to usefulness could fall into one or combination of the following - Helpfulness, Informational, Willingness to help, Confusion intensification, Unsolicited offer and Boorishness. Abubakar and Ilkan (2013) and Park and Gretzel (2007) noted that travellers can access a large amount of information that can help them make their travel plans and arrangement, but equally as found by Béliveau and Garwood (2001) and confirmed by this study the magnitude of information generated can cause 
confusion for the enquirer especially where conflicting information are volunteered. Confusion can emanate from those responses from contributors who are willing to help but lack knowledge, those who offer unsolicited alternatives and those who exhibit some sort of boorish behaviour. This can further intensify state of worry which according to Miceli and Castelfanchi, (2005) the traveller in the first place is devising strategies to relieve. Fischhoff at al. (2004) opined that confusion can affect trip experience or even lead to cancellation.

This study provides improvement on theoretical knowledge about the type of questions asked on TripAdvisor by developing the WOLF model. Based on previous discussions, queries raised by travellers (potential and actual) can be modelled based on two principal factors: level of information generated by a query on one hand, and perception of risk on the other hand. To this end, queries raised on TripAdvisor Forums are categorised into wonderland, onboard, lame duck and flagship queries. Whilst information provided on social media and review sites are ever increasing in magnitude, coupled with the fact that travellers and buyers of tourism products are increasingly depending on them, the usefulness of responses to questions raised by travellers would be optimised if the importance attached to them shapes the responses generated.

\section{Practical implications}

This study is in line with Pabel and Prideaux's (2016) call for DMOs to devise strategies to maximize the use of TripAdvisor and related platforms. Managers of destinations and marketers of tourism products, to this end, need to maintain presence on forum to provide clear and authoritative information that will aid tourists' 
decision making and subsequently enhance their experience. Managers may want to concentrate on Wonderland and Flagship queries as they have the tendency to produce large amount of information capable of creating confusion. Destinations may lose potential tourists who are unable to make a meaningful decision because of myriad and conflicting information emanating from diverse sources based on a wide range of worldviews. A potential traveller my find the process of sieving through voluminous amount of information stressful and hence may not be able to make a meaningful decision whether to visit a destination or not. In this type of case they may opt for a lesser tasking information processing option and visit another destination or choose another product whose information in less cumbersome. Apart from providing guidelines on maintaining an effective presence on TripAdvisor destination fora, the model can assist significantly in the design of 'frequently asked questions' web pages of destinations and individual organisations.

\section{Limitations and suggestions for further study}

As with all research studies a few issues have been identified that are classified as limitations of this present study. Some queries that did not receive any response were excluded from the analysis, although their lack of responses did not make them invalid questions. Time frame of questions and responses may be an issue for consideration. This study did not take into consideration responses that are delayed or not timely to the query. Equally, time of postings were not noted. Although time factor, in terms of responsiveness, did not feature in the study but it is reasonable to assume this may play a part in the magnitude of responses generated. This may be an area future study may want to examine. Also, this study presents a model which needs to be tested empirically. A quantitative study will be apt in testing this sense. 


\section{REFERENCES}

Abubakar, A. M., \& Ilkan, M. (2013). More adverts or more Ewom's. Journal of Business Financial Affairs, 2(2), 129.

Arsal, I., Woosnam, K. M., Baldwin, E. D., \& Backman, S. J. (2010). Residents as travel destination information providers: An online community perspective. Journal of Travel Research, 49(4), 400-413.

Banerjee, S. \& Chua, A. Y. K. (2016). In search of patterns among travellers' hotel ratings in TripAdvisor. Tourism Management, 53, 125-131

Béliveau, A., \& Garwood, J. B. (2001). The impact of new technologies on information research and purchasing behaviour of Quebec air travellers. Proceedings of the International Conference, Montreal, Canada.

Beeton, S. (2005). Film-induced tourism. Bristol: Channel View Publications.

Beeton, S. (2008). Location, location, location: Film corporations' social responsibilities. Journal of Travel and Tourism Marketing, 24(2-3), 107-114.

Bickart, B., \& Schindler, R. M. (2001). Internet forums as influential sources of consumer information." Journal of interactive marketing, 15(3), 31-40.

Bonifield, C., \& Cole, C. (2007). Affective responses to service failure: Anger, regret and retaliatory versus conciliatory responses. Marketing Letters, 18, 85-99.

Butler, G., \& Matthews, A. (1987). Anticipatory anxiety and risk perception. Cognitive Therapy and Research, 11, 551-565.

Butler, R. (2011). It's only make believe: The implications of fictional and authentic locations of film. Worldwide Hospitality and Tourism Themes, 3(2), 91-101.

Chatterjee, P. (2001). Online Reviews: Do Consumers Use Them? Advances in Consumer Research, 28(1), 129-133. 
Chen, X-H (2017). A novel support model for satisfactory restaurants utilizing social information: A case of TripAvisor.com. Tourism Management, 59, 281-297

Crotts, J. (1999). Consumer decision making and prepurchase information search. In Consumer behavior in travel and tourism, edited by A. Pizam and Y. Mansfeld, 149-168. New York: The Haworth Press.

Dabholkar, P. (1990). How to Improve Perceived Service Quality by Improving Customer Participation in Developments in Marketing Science. 483-487

Davis, A., \& Khazanchi, D. (2008). An empirical study of online word of mouth as a predictor for multi-product category e-commerce sales. Electronic markets, 18(2), 130-141.

DiMaggio, P., Hargittai, E., Neuman, W. R., \& Robinson, J. P. (2001). Social implications of the Internet. Annual review of sociology, 27(1), 307-336.

Fischhoff, B., de Bruin, W. B., Perrin, W., \& Downs, J. (2004). Travel risk in a time of terror: judgements and choices. Risk Analysis (24) pp 1301-1309.

Fodness, D., \& Murray, B. (1997). Tourist information search. Annals of tourism research, 24(3), 503-523.

Freeston, M. H., Rhéaume, J., Letarte, H., Dugas, M. J., \& Ladouceur, R. (1994). Why do people worry?. Personality and individual differences, 17(6), 791-802.

Glaser, B., \& Strauss, A. (1967). The discovery of grounded theory. London: Weidenfeld and Nicholson, 24(25), 288-304.

Godes, D., \& Mayzlin, D. (2004). Using online conversations to study word-of-mouth communication. Marketing science, 23(4), 545-560.

Goffman, E. (1959). The Presentation of Self in Everday Life. Harmondsworth: Penguin 
Gretzel, U., Yoo, K. H., \& Purifoy, M. (2007). Online Travel Review Study: Role \& Impact of Online Travel Reviews, Laboratory for Intelligent System in Tourism. Haldrup, M., \& Larsen, J. (2010). Tourism, performance and the everyday: Consuming the Orient. London: Routledge.

Lincoln, Y. S. and Guba, E. G. (1985) Naturalistic Inquiry, Newbury Park, CA: Sage Publications.

Hennig-Thurau, T., Gwinner, K. P., Walsh, G., \& Gremler, D. D. (2004). Electronic word-of-mouth via consumer-opinion platforms: What motivates consumers to articulate themselves on the Internet? Journal of interactive marketing, 18(1), $38-52$.

Inversini, A., Cantoni, L., \& Buhalis, D. (2009). Destinations' information competition and web reputation. Information technology \& tourism, 11(3), 221-234.

Jalilvand, M. R., \& Samiei, N. (2012). The impact of electronic word of mouth on a tourism destination choice: Testing the theory of planned behavior (TPB). Internet Research: Electronic Networking Applications and Policy, 22(5), 591612.

Kiecker, P. \& Cowles, D. (2001). Interpersonal Communication and Personal Influence on the Internet: A Framework for Examining Online Word-of-Mouth. Internet Applications in Euromarketing, 11(2), 71-88.

Kietzmann, J. H., Hermkens, K., McCarthy, I. P., \& Silvestre, B. S. (2011). Social media? Get serious! Understanding the functional building blocks of social media. Business horizons, 54(3), 241-251.

Kim, J. J., Fesenmaier, D. R., \& Johnson, S. L. (2013, July). The effect of feedback within social media in tourism experiences. In International Conference of 
Design, User Experience, and Usability (pp. 212-220). Springer, Berlin, Heidelberg.

Kladou, S., \& Mavragani, E. (2015). Assessing destination image: An online marketing approach and the case of TripAdvisor. Journal of Destination Marketing \& Management, 4(3), 187-193.

Kotler, P. (1986). The prosumer movement: A new challenge for marketers. In J. Richard (Vol. Ed.), NA - Advances in consumer research. 13, (pp. 510-513). Lutz, Provo, UT: Association for Consumer Research.

Larsen, S., Brun, W. and Øgaard, T. (2009) What tourists worry about - Construction of a scale measuring tourist worries. Tourism Management 30 (2009) 260-265

Li, S. C., Robinson, P., \& Oriade, A. (2017). Destination marketing: The use of technology since the millennium. Journal of destination marketing \& management, 6(2), 95-102.

Liu, Y., Teichert, T., Rossi, M., Li, H \& Hu, F. (2017) Big data for big insights: Investigating language-specific drivers of hotel satisfaction with 412,784 usergenerated reviews, Tourism Management, 59 (2017), 554-563.

Litvin, S. W., Goldsmith, R. E., \& Pan, B. (2008). Electronic word-of-mouth in hospitality and tourism management. Tourism management, 29(3), 458-468.

Lusch, R. F., \& Vargo, S. L. (2006). The service-dominant logic of marketing: Reactions, reflections, and refinements. Marketing Theory, 6(3). pp. 281-288

Meuter, M.L., Ostrom, A.L., Roundtree, R.I., and Bitner, M.J. (2000). Self-Service Technologies: Understanding Customer Satisfaction with Technology Based Service Encounters. Journal of Marketing 64 (3). pp. 0-64.

Mayzlin, D. (2006). Promotional chat on the Internet. Marketing Science, 25(2), 155163. 
Miceli, M., \& Castelfanchi, C. (2005). Anxiety as an "epistemic" emotion: an uncertainty theory of anxiety. Anxiety, Stress, and Coping, 18(4) pp 291-319. Michalko, G., Irimias, A. and Timothy, D. (2015) Disappointment in tourism: Perspectives on tourism destination management. Tourism Management Perspectives 16 (2015) 85-91

Miguéns, J., Baggio, R. and Costa, C., (2008). Social media and tourism destinations: TripAdvisor case study. Advances in Tourism Research, 26(28), pp.26-28.

Munt, I. (1994) The 'Other' Post-modern Tourism: Culture, Travel and The New Middle Class, in Theory, Culture \& Society, Vol. 11, pp 101-23.

Mizrachi, I., \& Fuchs, G. (2016). Should we cancel? An examination of risk handling in travel social media before visiting ebola-free destinations. Journal of Hospitality and Tourism Management, 28, 59-65.

O'Connor, P., (2008). User-generated content and travel: A case study on Tripadvisor. com. Information and Communication Technologies in Tourism, pp.47-58.

O'Dell, T., \& Billing, P. (Eds.). (2005). Experiencescapes: Tourism, culture and economy. Copenhagen Business School Press DK.

Pabel, A., \& Prideaux, B. (2016). Social media use in pre-trip planning by tourists visiting a small regional leisure destination. Journal of Vacation Marketing, 22(4), 335-348.

Pappalepore, I. Maitland, R. and Smith, A. (2014) Prosuming creative urban areas. Evidence from East London in Annals of Tourism Research 44 (2014). pp. 227240 
Park, Y. A., \& Gretzel, U. (2007). Success factors for destination marketing web sites: A

qualitative meta-analysis. Journal of Travel Research, 46(1), 46-63.

Prebensen, N.K. \& Foss, L. (2011). Coping and Co-creating in Tourist Experiences in The International Journal of Tourism Research 13. pp. 54-67

Rakic, T., \& Chambers, D. (2012). Rethinking the consumption of places. Annals of Tourism Research, 39(3). pp. 1612-1633

Ridings, C. M., Gefen, D., \& Arinze, B. (2002). Some antecedents and effects of trust in virtual communities. The Journal of Strategic Information Systems, 11(3-4), 271-295.

Ritzer, G., Dean, P., \& Jurgenson, N. (2012). The Coming of Age of the Prosumer. American Behavioral Scientist 2012 56: 379

Ritzer, G. (2009). Correcting an Historical Error, keynote address at the Conference on Prosumption, Frankfurt, Germany, March.

Robinson, P., Lueck, M., \& Smith, S. (2013). Tourism. Wallingford: CABI.

Shaw, G. \& Williams, A. (2004) Tourism and Tourism Spaces. London: Sage

Silverman, G. (2001). The power of word of mouth. Direct Marketing, 64(5), pp. 4752.

Smith, E., Fredrickson, B., Loftus, G., \& Nolen-Hoeksema, S. (2003). Atkinson and Hilgard's introduction to psychology. Belmont: Thomson-Wadsworth.

Stepchenkova, S., Mills, J., \& Jiang, H. (2007). Virtual travel communities: Selfreported experiences and satisfaction. Information and communication technologies in tourism 2007, 163-174. 
Tham, A., Croy, G., \& Mair, J. (2013). Social media in destination choice: Distinctive electronic word-of-mouth dimensions. Journal of Travel \& Tourism Marketing, $30(1-2), 144-155$.

Toffler, A. (1980). The third wave. New York, NY: Bantam Books.

Tsaur, S. H., Huang, C. C., \& Luoh, H. F. (2014). Do travel product types matter? Online review direction and persuasiveness. Journal of Travel \& Tourism Marketing, 31(7), 884-898.

Tussyadiah, I. P., \& Fesenmaier, D. R. (2009). Mediating tourist experiences: Access to places via shared videos. Annals of Tourism Research, 36(1), 24-40.

Urry, J. (2002). The Tourist Gaze, Second Edition, London: Sage

Vygotsky, L. S. (1978). Mind in Society: the development of higher mental processes. Cambridge: Harvard University Press.

White, N. R., \& White, P. B. (2007). Home and away: Tourists in a connected world. Annals of Tourism Research, 34(1), 88-104.

Xia, L., \& Bechwati, N. N. (2008). Word of mouse: the role of cognitive personalization in online consumer reviews. Journal of interactive Advertising, 9(1), 3-13.

Xiang, Z., \& Gretzel, U. (2010). Role of social media in online travel information search. Tourism management, 31(2), 179-188.

Xie, C., Bagozzi, R.P. \& Troye. S.G. (2008). Trying to Prosume: Toward a Theory of Consumers as Co-Creators of Value, Journal of the Academy of Marketing Science, 36, pp. 109-122.

Zhang, H. Y., Ji, P., Wang, J. Q., \& Chen, X. H. (2017). A novel decision support model for satisfactory restaurants utilizing social information: A case study of TripAdvisor. com. Tourism Management, 59, 281-297. 